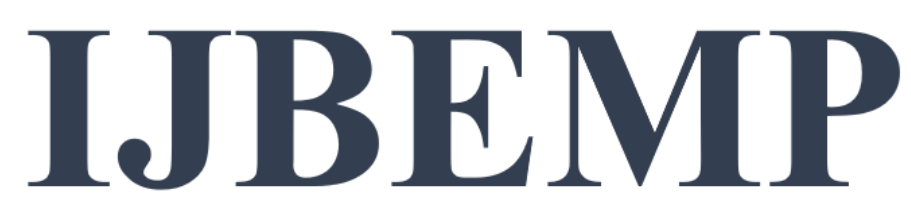

International Journal of Business, Economics and Management Perspectives Uluslararası İşletme, Ekonomi ve Yönetim Perspektifleri Dergisi
ISSN: $2458-8978$

E-ISSN : 2458-8978

YIl Year: 6

Cilt Volume. 5

Sayı Issue: 2

Aralık December 2021

\title{
İŞ BECERİKLİLİĞİ ÜZERİNE KAVRAMSAL BİR İNCELEME
}

\section{Kübra ÖZGENÇ}

Yüksek Lisans Öğrencisi, Süleyman Demirel Üniversitesi, Sosyal Bilimler Enstitüsü, İşletme Anabilim Dalı, Isparta, Türkiye.

E-posta: kubraozgenc07@gmail.com ORCID: 0000-0002-7133-3879

\section{Tuğba ERHAN}

Dr. Öğr. Üyesi Süleyman Demirel Üniversitesi, İktisadi ve İdari Bilimler Fakültesi, İşletme Bölümü, Isparta, Türkiye.

E-posta: tugbaerhan@sdu.edu.tr ORCID: 0000-0002-5697-490X

Makale geliş tarihi: 30.09.2021 Makale kabul tarihi: 15.12.2021 iThenticate benzerlik oranı: \% 12

Kaynak gösterimi (APA 6):

Özgenç, K., \& Erhan, T. (2021). İş Becerikliliği Üzerine Kavramsal Bir İnceleme. Uluslararası İşletme, Ekonomi ve Yönetim Perspektifleri Dergisi (IJBEMP), 5(2), 732-748. 


\title{
IŞS BECERIKLILIIĞİ ÜZERINE KAVRAMSAL BİR İNCELEME
}

\section{ÖZET}

Yakın zamanda kavramsal çerçevesi oluşturularak literatüre kazandırılan İş Becerikliliği (Job Crafting) kavramı, çalışanın iş becerisi ve motivasyonunu artırmaya yönelik iş ve görev tanımıla ilgili sınırlarını, fiziksel ve bilişsel açıdan kendi isteğiyle bilinçli olarak değiştirip genişletmesi süreci olarak nitelendirilmektedir. Ulusal alan yazında henüz fazla araștırma değeri görmemesine rağmen, özellikle uluslararası, pozitif örgütsel psikoloji alanında; yaratıcı ve motivasyonel alt yapılı çalışan davranışlarını tetiklemesi ve işe ilişsin pozitif anlamlılık, benlik duygusu, örgütsel bağlılık, adanmışlık ve performans deneyimi gibi üretken sonuç odaklı davranış sağlaması sebebiyle önemini giderek artırmaktadır. Çalışma İş Talepleri ve Kaynakları Modeli (JD-R) ve İş̧ Tasarımı Teorisi çerçevesinde şekillendirilmiş ve iş becerikliliğinin farklı yazarlarca ortaya konulan boyutlandırmaları incelenmiştir. İlişkili olduğu diğer kavramlar ve ilgili alan araştırmacıları tarafından edinilen bulgular ele alındığında, iş becerikliliği ile iş sağlığı ve güvenliği kavramlarının ortak olgusunun 'kişi-iş uyumu' olduğu düşünülerek gelecek çalışmalara öneri niteliğinde sunulmuştur.

Anahtar Kelimeler: İs Becerikliliği, Örgütsel Vatandaşlık Davranışı, Rol Yenilikçiliği, Görev Revizyonu, Bireysel İisiyatif Alma

JEL Sinıflandırma Kodları: D 23, C 91, M 12

\section{A CONCEPTUAL REVIEW ON JOB CRAFTING}

\begin{abstract}
The concept of job crafting, which has recently been introduced to the literature by creating a conceptual framework, is described as the process of changing and expanding the limits of job and task definition in order to increase the job skill and motivation of the employee consciously from the physical and cognitive perspective. Although the term has not yet received much attention in the national research field, it is increasingly important in the field of international, positive organizational psychology as it triggers creative and motivational worker behaviors and provides productive outcome-oriented behavior such as positive meaning about work, sense of self, organizational commitment, engagement and performance experience. The current study has been shaped within the theoretical framework of Job Demands and Resources Model (JD-R) and Job Design Theory and different dimensions of job crafting stated by various theorists have been examined. When the other related concepts and the findings obtained by the relevant field researchers have been considered, the study is presented as a suggestion for further studies highlighting the common phenomenon of the concepts of job crafting and occupational health and safety as "person-job fit".
\end{abstract}

Keywords: Job Crafting, Organizational Citizenship Behaviour, Role Innovation, Task Revision, Personal Initiative

JEL Classification Codes: D 23, C 91, M 12 


\section{GİRIŞ}

Organizasyonlar, sürdürülebilirlik kazanımında işlerini yaptırabilecek, onları tamamlayıcı yardımcılara yani çalışanlara ihtiyaç duyarlar. Bu çalışanlar arasında işle olan meşguliyeti daha az olanlara kıyasla, işe kendini verme oranı daha yüksek olan kişilerin, yüksek iş performansı gibi pozitif örgütsel çıktılar sağlaması sebebiyle tercih edilebilirliği daha fazla olmaktadır.

İşletme başarısı ile birlikte yükselen performans verimliliği, çalışan motivasyonuyla paralel şekilde işlemektedir. Wrzesniewski ve arkadaşlarına (2013) göre, çalışan motivasyonunun sağlanması; iş yeri koşullarının iyileştirilmesi ve çalışanın kişisel özellik ve becerilerine önem verilmesi ile mümkündür. Günümüz organizasyon yapıları, çalışanların görev ve sorumluluklarında kendi fiziksel ve bilişsel becerilerini kullanma inisiyatifini genellikle göz ardı etmektedir. Bu durumun doğuracağ1 olumsuz sonuçlardan örgütlerin korunması için ise, çalışanların iyi oluşlarını ve iş motivasyonunu koruyan 'iş becerikliliği' davranışına yönelimin etkili sonuçlar doğuracağı ileri sürülmektedir (Wang vd., 2017: 187).

Çalışanların işleri üzerinde kendi mahirlikleriyle yeniden tasarımda bulunmaları yakın geçmişte araştırma konusu edinilse de, iş becerikliliği kavramsal olarak, ancak son yıllarda iş ve organizasyon alanı uzmanlarının dikkatini çekmeye başlamıştır. 'İş Becerikliliği (Job Crafting)' Amy Wrzesniewski ve Jane E. Dutton tarafından (2001: 179) literatüre kazandırılarak; "bireylerin görev veya çalışmalarının ilişkisel sinırlarında yaptıkları fiziksel ve bilişsel değiş̧iklikler" olarak tanımlanmışıı.

Sürekli değişen iş dünyasının dinamizmine uyum sağlamak ve belirsizliklerle başa çıkmak için; çalışanların işinde aktif rol üstlendiği ve işe ilişkin dönüşümleri öngörerek yenilikçi değişikliklerin yaratılmasını sağlayan (Petrou vd., 2012: 1120) iş becerikliliği bakış açılı davranış yaklaşımı, örgüt yaşamı açısından hayati önem taşımaktadır.

$\mathrm{Bu}$ çalışma ile örgütsel psikoloji alanına katkı sunan iş becerikliliği kavramının, tarihsel süreçteki gelişimini, alandaki araştırmacıların iş becerikliliği boyutlandırmalarını ve iş becerikliliğinin ilişkili olduğu kavramları ele alınarak kavramsal bir çerçeve oluşturulması amaçlanmıştır.

\section{2. İŞ BECERIKLILIIĞİIIN KAVRAMSAL ÇERÇEVESİ}

Tarihsel gelişim içerisinde, çalışanların işlerini şekillendirmek için bireysel karar almalarının gerektiği düşüncesi Katz ve Kahn'ın (1966) rol yenilikçiliği (role innovation) kavramını ileri sürmesiyle başlamış; Bell ve Staw'un (1989) organizasyonlardaki 'çalışan kontrollü roller' üzerine gerçekleştirdiği şekil verme (scultping activities) ve ardından Staw ve arkadaşları (1990) tarafından önerilen görev revizyonu (task revision) kavramlarının doğması ile de iş becerikliliği oluşumu hız kazanmıştır (Yavuz ve Artan, 2019: 99).

Kulik, Oldham ve Hackman tarafindan 1987 yılında yapılan çalışmada, işin yeniden tasarlanma sürecine ilişkin yöntem belirtilirken, "kişilerin kendi ihtiyaçları ile becerileri arasında uyumu geliş̧irmek için işlerinde hangi değiş̧ikliklerin yapılacă̆ını belirlemede aktif olarak rol aldiğl ve çalı̧̧anların bazen işlerini kendi inisiyatifleriyle yeniden tasarlayabildiği, yönetici veya örgüt onayının gerekmediği katılımcı bir değişim stratejisi" ş̧eklindeki tanımlamayla aslında bugünkü 'iş becerikliliği' kavramının temelleri atılmıştır (Rudolph vd., 2017: 113).

2001 yılına gelindiğinde, Wrzesniewski ve Dutton (2001: 179) tarafindan, ilk kez 'İş Becerikliliği (Job Crafting)' olarak “çalışanın iş becerisi ve motivasyonunu artırmak üzere iş ve görev tanımıyla ilgili sınırlarını, fiziksel ve bilişsel açıdan kendi isteğiyle bilinçli olarak değiştirip genişletmesi süreci” şeklinde tanımlanmıştır. Burada fiziksel değişim sınırları, çalışan bireyin işin formunda, kapsamında ya da görev sayısı üzerinde gerçekleştirdiği değişimleri; bilişsel değişim sınırları ise kişinin işi nasıl görüp tanımladığına yönelik değişikleri ifade etmektedir (Demerouti, 2014: 238).

Sonraki y1llarda Slemp ve Vella-Brodrick (2013: 126) ise iş becerikliliğinin "formal olmayan bir süreç içerisinde, çalışanların bireysel kontrol ile işlerini yeniden tasarlaması sonucunda iş ile bireysel çıkarların aynı dengede buluşması durumu" olduğu ifadesinde bulunmuşlardır. Burada formal olmayan yani informal süreçten kasıt, çalışanların herhangi bir emre tabi olmadan, kendilerine özgü değer, yetenek ve tercihler ile iş uygulamalarını gerçekleştirmeleridir. Genel çerçevede ele alındığında, iş 
becerikliliği; çalışanların, kendi inisiyatifleriyle işlerinde gerçekleştirdikleri değişikliklerdir (Tims vd., 2016: 45). Aşağıda Şekil 1'de iş becerikliliği modeli görülmektedir.

Şekil 1: İş Becerikliliği Modeli

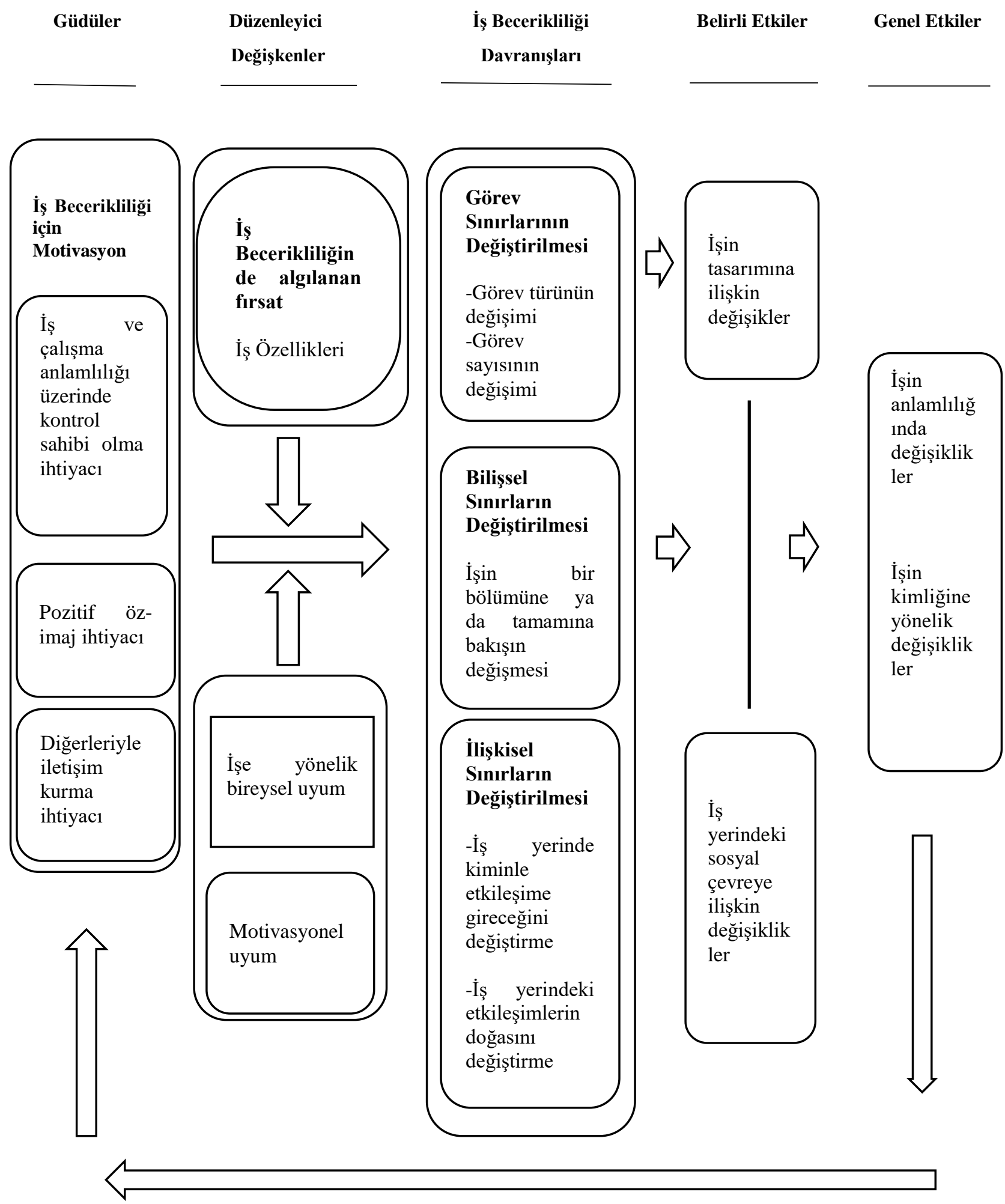

Kaynak: Wrzesniewski ve Dutton, 2001: 18.

Şekil 1'de iş becerikliliği modeli incelendiğinde iş becerikliliği kavramının; güdü faktörleri, düzenleyici değişkenler, iş becerikliliği davranışları, belirli etkiler ve genel etkiler başlıklarıyla ele 
alındığı görülmektedir. Modelde iş özelliklerinin ve bireyin işe uyumunun, iş becerikliliği güdüsü ile iş becerikliliği davranışları arasında düzenleyici etkiye sahip olduğu ileri sürülmektedir.

İş becerikliliğine ilişkin öncül varsayım, çalışanların işlerini yapılandırırken iş unsurlarını aktif bir şekilde kullanmalanıdır (Wang vd., 2017: 186). Diğer bir ifadeyle bireylerin çalışmalarının sınırlarını proaktif olarak değiştirip şekillendirebilecekleri sürekli bir süreç olmalıdır (Berg vd., 2010: 159). Görevlerinde proaktif rol sergileyen çalışanlar, kişi-iş uyumu yakaladıklarında monotonluktan uzak kendileri için eğlenceli bir görev akışı yaşayabilirler (Grant ve Ashford, 2008:12; Berg vd., 2013: 4). Aynı zamanda mevcut koşullara pasif olarak adapte olmaktan ziyade statükoya meydan okur (Crant, 2000: 436) ve mevcut koşullarını iyileştirmek için inisiyatif alırlar. Diğer bir ifadeyle, kişiliklerini ve/veya çevreyi değiştirerek farklı bir gelecek öngörürler ve plan yaparlar (Parker vd., 2010: 831).

İş becerikliliğinin diğer bir öncül varsayımı, yöneticilerin değil çalışanların 'sürücü koltuğuna' konulduğu ve çalışanların kendi iş özellikleri perspektifinden küçük değişimler yaparak işlerini yeniden tasarladıkları bir süreci kapsamasıdır (Berg vd., 2013: 2). Bu doğrultuda iş becerikliliğinin davranışsal olarak geleneksel idarecilik yaklaşımından (yukarıdan-aşağıya) farklılaşarak aşağıdan-yukarıya yaklaşımı benimsediği görülmektedir (Wingerden vd., 2017: 165).

Wrzesniewski ve Dutton (2001: 181) tarafından öne sürülen iş becerikliliği modelinde bireylerin işleri üzerinde gerçekleştirdiği değişimler "günlük" zaman kıstasıyla ele alınmaktadır. Buradaki günlük nitelemesi, işlerin günlük periyotta yeniden oluşturulmasını ifade etmektedir. Buradan çıkarımla, çalışanların belirgin iş tanımları ve iş prosedürlerine sahip olduğu çalışma ortamında, görevleri üzerinde günlük ayarlamalarda bulunabildiklerini söylemek mümkündür (Shin ve Hur, 2019: 2).

İş becerikliliğine ilişkin çalışmalarda bulunan araştırmacılar, iş becerikliliği motivasyonunun üç bireysel ihtiyaçtan doğduğunu ileri sürmüşlerdir. İlk olarak, çalışanlar işten yabancılaşmayı önlemek maksadıyla, işleri üzerinde bazı kontroller sağlamak için iş becerikliliği yapmaktadır. İkinci olarak, çalışanlar işlerinde pozitif bir öz-imaj yaratmak için motive olmaktadır. Son olarak, iş becerikliliği çalışanların diğer bireylerle bağlantı kurmaları için temel bir insan ihtiyacının yerine getirilmesini sağlamaktadır (Wrzesniewski ve Dutton, 2001: 181).

Literatür incelendiğinde iş becerikliliği kavramının teorik çerçevesinin İş Tasarımı Teorisi ve İş̧ Talepleri ve Kaynakları Modeli çerçevesinde tanımlandığı söylenebilir. İş Tasarım Teorisine göre; çalışanların yaptıkları işler, çalışanlarda olumlu etki oluşturacak şekilde tasarlandığında, çalışanların işlerinde ve görevlerinde daha fazla zaman ve enerji harcaması muhtemeldir (Alfes vd., 2015: 2482). İş tasarımında veya işin yeniden tasarlanmasında, yapılan işte bir bütün olarak değişiklikler yapılmakta ve söz konusu değişiklik yukarıdan aşağıya doğru gerçekleşmektedir; ancak 'Alternatif iş tasarımı tekniği' bakış açısı ile iş becerikliliğinde, çalışanlar tarafından aşağıdan yukarıya (bottom up) doğru bir yaklaşım benimsenerek, işlerin bizzat çalışanlar tarafından tasarlanması düşüncesi ön plana çıkmaktadır (Yavuz, 2018: 12).

Tims ve Bakker (2010) tarafından ileri sürülen İş Talepleri ve Kaynakları (JD-R) modelinde ise, iş becerikliliği, çalışanın kendi işini daha anlamlı, ilgi çekici ve tatmin edici hale getirmek için iş talepleri ve iş kaynaklarında değişiklikler yaptığı proaktif bir davranış biçimini ifade etmektedir (Kerse, 2019: 207).

\section{3. İŞ BECERİKLİĞİNIN BOYUTLARI}

İş becerikliliği kavramına ilişkin literatürde farklı yazarlar tarafından farklı boyutlar geliştirilmiştir. Bunlar arasında öne çıkanlar ise; Wrzesniewski ve Dutton tarafından yapılan boyutlandırma, Berg Grant ve Johnson tarafından yapılan boyutlandırma, Tims, Bakker ve Derks tarafindan yapılan boyutlandırma, Slemp ve Vella-Brodrick tarafindan yapılan boyutlandırma ve Petrou, Demerouti ve Schaufeli tarafindan yapılan boyutlandırmalardır.

\subsection{Wrzesniewski ve Dutton Tarafından Yapılan Boyutlandırma}

İş becerikliliğine ilişkin yapılan ilk boyutlandırma Wrzesniewski ve Dutton tarafından gerçekleştirilmiş olup; Görev Becerikliliği (Task Crafting), İlişkisel Beceriklilik (Relational Crafting) ve Bilişsel Beceriklilik (Cognitive Crafting) aşağıda özetlenen şekilde üç boyutta ele alınmıştır (Wrzesniewski ve Dutton, 2001: 185): 
Görev Becerikliliği Boyutu: Çalışanların iş yerinde, iş görevlerinin sayısına, kapsamına ve türüne ya da görev içeriğine yönelik değişiklikler yaparak kendilerine farklı bir iş yaratmalarıdır. Görev becerikliliği, resmi bir iş tanımı tarafından belirlenen sorumlulukların değiştirilerek, yeni görevlerin eklenmesi ya da bırakılması şeklinde görevlerin doğasında yapılan değişiklikler veya görevlere ayrılan zaman, enerji ve dikkat düzeylerinde gerçekleştirilen değişiklikleri içermektedir. Örneğin; teknolojiye ilgi duyan bir İK uzmanın, işe alım için sosyal medyayı kullanarak işine anlamlı bulduğu görev eklemesi gibi (Berg vd., 2013: 8).

İlişkisel Beceriklilik Boyutu: Bireylerin, iş ortamında başkaları ile etkileşimlerinin kalitesi veya miktarında ya da her ikisinde de değişiklik gerçekleştirmeleridir. Daha açık bir ifadeyle çalışanın etkileşime girdiği insanlar hakkında takdir yetkisini kullanmasıdır (Başpınar ve Çakıroğlu, 2020: 14). İlişkisel beceriklilik, çalışanların işlerini, ilişkilerini veya iş kapsamını önem seviyesini değiştirecek şekilde algılayıp yorumlama çabalarını içermektedir (Wrzesniewski vd., 2013: 281). Çalışanların işlerinin yürütülmesinde nasıl, ne zaman veya kiminle etkileşimde bulunacağına dair yaptıkları değişiklikler ilişkisel beceriklilik kapsamındadır. Örneğin, bir pazarlama analisti ile işbirlikçi bir ilişki kuran bir yazilım mühendisi gibi (Berg vd., 2013: 3).

Bilişsel Beceriklilik Boyutu: Bilişsel sınırların değiştirilmesi birçok biçim alabilir; ancak daha çok çalışanların bir dizi iş görevi veya bütünsel şekilde zihinlerinde işi nasıl ayrıştırıp, değiştirdiğini içermektedir. İş görünümünü bu açıdan değiştirmek, çalışanların temelde işe yaklaşım biçimini de değiştirmektedir. İş becerikliliğine ilişkin ortaya konulan bu üç boyut, birbirlerini herhangi bir şekilde engellemeyerek, çalışan tarafindan entegre kullanılmaya olanak sağlamaktadır. Örneğin; bir finans şirketinde yeni bir sosyal medya grubuna dahil olan bir çalışan, üyeler için eğitim aktiviteleri gibi görevler eklendiğinde, iş arkadaşları ile tanışabilir ve diğerleriyle etkileşimde bulunma firsatı bulabilir. Aynı zamanda iş birliği yaparak ilişkilerine yön verebilir ve işini artık farklı biçimde görmeye başlayabilir. Böylelikle de kendisinde var olan sosyal pazarlama tutkusu için ortam yaratabilmektedir (Wrzesniewski vd., 2013: 283). Niessen ve arkadaşları (2016: 1289) bilişsel becerikliliğin; iş ve iş kimliklerinin anlamını değiştirerek, bireylerin çalışma ortamına uyum sağlamasında önemli bir proaktif strateji olduğunu ifade etmektedir. Bilişsel beceriklilik davranışı ile çalışanlar, işlerinin kapsamındaki görevleri ve ilişkileri algılama biçimlerinde anlamlı yenilikler yaparlar. İş becerikliliğine ilişkin bu üç davranış biçimi, çalışanın yaptığı işte kontrolün kendisinde olduğunu hissetmesini, işi kavramasını ve diğer çalışanlarla etkili iletişim kurmasını sağlamaktadır. Bu durumda çalışan aktif role bürünerek pasif bir örgüt unsuru olmaktan ayrılmaktadır (Kerse, 2017: 285).

\subsection{Berg, Grant ve Johnson Tarafindan Yapılan Boyutlandırma}

Berg, Grant ve Johnson tarafından yapılan çalışmada iş becerikliliği; İş Esnasında Beceriklilik (Job Crafting) ve İş Dışı Zamanlardaki Beceriklilik (Leisure Crafting) olmak üzere aşağıda özetlenen iki boyutta ele alınmıştır (Berg vd., 2010: 979- 984):

İş Esnasında Beceriklilik Boyutu: Görev üzerinde durmak (task emphasizing), iş genişletme (job expanding) ve rolü yeniden çerçevelendirmek (role reframing) şeklinde üç alt boyut ile açıklanmıştır. Görev üzerinde durmak, daha önceden belirlenen görevlerin niteliğinde değişiklik yapmak veya net görevler için daha fazla zaman ve enerji harcamak; iş genişletme, çalışanın kısa süreli veya geçici olarak yeni görevler üstlenmesi ve son olarak rolü yeniden çerçevelendirmek ise, işin geleneksel sosyal amacıyla bilişsel bir etkileşim sağlamak biçiminde tanımlanmaktadır. Araştırmacılar çalışanları, iş becerikliliği ile görevleri arasında uyum yakalamaya motive eden; görev üzerinde durmak, iş genişletme ve rolü yeniden çerçevelendirmek boyutlarının; bireylerin hayallerindeki ve fiilen gerçekleşen iş deneyimleri arasında daha uyumlu bir ilişki yarattığını ileri sürmektedir.

İş Dışı Zamanlardaki Beceriklilik Boyutu: Dolaylı olarak deneyim (vicarious experiencing) ve hobilere iştirak etmek (hobby participating) şeklinde iki alt boyutta değerlendirilmiştir. Dolaylı olarak deneyim; çalışanın iş becerikliliği ile belirlenen görevler arasında uyum algılamadığında; aile, arkadaşlar ya da ünlüler gibi başkaları aracılığıyla dolaylı olarak keyifli ve anlamlı deneyim sağlanmasıdır. Hobilere iştirak etmek; bireylerin algıladıkları görev ile kendi amaç ve isteklerinin uyumlu olmadığı koşullarda, iş dışı zamanlarında gönüllü olarak beceriklilik faaliyetlerine katılmalarını içermektedir. Çalışmada, çalışanların bireysel arzuları doğrultusunda iş yerinde yapılması mümkün olmayan beceriklilik faaliyetlerini boş zamanlarında sürdürdügü gözlemlenmiştir. 


\subsection{Tims, Bakker ve Derks Tarafından Yapılan Boyutlandırma}

Tims, Bakker ve Derks İş Talepleri-Kaynakları (JD-R) Modeli çerçevesinde iş becerikliliğini Sosyal İş Kaynaklarını Arttırmak (Increasing Social Job Resources), Yapısal İş Kaynaklarını Arttırmak (Increasing Structural Job Resources), Zorlu İş Taleplerini Arttırmak (Increasing Challenging Work Demands) ve Engelleyici İş Taleplerini Azaltmak (Decreasing Hindering Work Demands) olmak üzere aşağıda özetlenen dört boyuta incelemişlerdir (Tims vd., 2012: 174-177):

Sosyal İş Kaynaklarını Artırma Boyutu: Çalışanların üstlerinden ya da çalışma arkadaşlarından geri bildirim alma, destek alma, tavsiyede bulunma ya da mentorluk gibi çevresiyle sürdürdüğü etkileşimini geliştirerek, iş kaynaklarını artırma davranışlarını kapsamaktadır.

Yapısal İş Kaynaklarını Artırma Boyutu: Çalışanın kendisinden istenilenleri yerine getirebilmek için gelişim firsatları, beceri çeşitliliği ve özerklik gibi çeşitli karakteristik özellikleri artırmaya yönelik yaptığı uygulamalar olarak adlandırılmaktadır.

$\mathrm{Bu}$ iki boyut arasındaki fark, yapısal iş kaynaklarını arttırma boyutu yapılan işle ilgili olarak daha fazla çeşitlilik, sorumluluk ve bilgi gerektirdiği için, iş tasarımında daha fazla etkiye sahip olacaktır; sosyal iş kaynaklarını arttırma boyutu ise kendini geliştirme ve etkileşim firsatı sunduğu için, işin sosyal yönleri üzerinde bir etki yaratacaktır.

Zorlu İş Taleplerini Artırma Boyutu: Çalışanın daha fazla sorumluluk istemesi ve özel projeler için gönüllü olma gibi davranışları sergilemeyi içermektedir. Örneğin; çalışanın proaktif olarak yeni bir proje başlatması gibi.

Engelleyici İş Taleplerini Azaltma Boyutu: Çalışanların iş yükünü ve iş-aile çatışmasını azaltmak gibi fiziksel, bilişsel ve duygusal taleplerini en aza indirmeyi amaçlayan davranışları gerçekleştirmesidir (Rudolph vd., 2017). Örneğin, duygusal etkileşimlerin veya bilişsel görevlerin sayısının azaltılması gibi. Bireyler, taleplerinin bunaltıcı hale geldiğini algıladıklarında iş taleplerinin seviyesini proaktif olarak azaltabilirler (Tims vd., 2012: 175). Tims ve arkadaşları (2015) tarafından yapılan deneysel araştırmada, bir kişinin engelleyici iş taleplerini sürekli azaltarak iş becerikliliği davranışında bulunduğunda, bu durumun çalışma arkadaşlarına daha fazla iş yükü olarak yansıyarak tükenmişliğe yol açtığı sonucuna varılmıştır (Yavuz, 2018: 32).

\subsection{Slemp ve Vella-Brodrick Tarafindan Yapılan Boyutlandırma}

Slemp ve Vella-Brodrick iş becerikliliğinin görev, ilişkisel ve bilişsel olmak üzere aşağıda özetlenen üç boyutunun, çalışanların iş deneyimlerini bireysel olarak şekillendirebileceklerini, farklı ancak anlamlılık kazandıran üç yolu temsil ettiğini ileri sürmüş̧ür (Slemp ve Vella-Brodrick, 2013: 129).

Görev Becerikliliği Boyutu: Çalışanların işlerine ilişkin belirli faaliyetleri eklenmesi veya ortadan kaldırılması, çeşitli iş görevlerinde harcanan zaman veya emek miktarının değiştirilmesi veya net olan bir görevin belirli yönlerine yönelik yeniden tasarımda bulunmasını içermektedir (Miller, 2015: 33). Görev becerikliliğinde davranışında, işe ilişkin revizyonlar yapılarak (örneğin; kişinin yeteneğine ve ilgisine göre yeni görevler belirlemesi), işi ile çalışanın bireysel ihtiyaç ve yetenekleri ile uyumlu hale getirilir (Slemp ve Vella-Brodrick, 2013).

İlişkisel Beceriklilik Boyutu: İş yerinde başkaları ile ilişkiler oluşturmayı, sürdürmeyi, değiştirip dönüş̧ürmeyi ya da ortadan kaldırmayı içerir (Miller, 2015: 33). Ghitulescu (2007: 201) tarafından yapılan araştırmada, ilişkisel becerikliliğin çalışan verimliliğini olumlu yönde etkilediği sonucuna ulaşılmıştır. Aynı çalışmada, daha fazla inisiyatif alarak görevlerini şekillendiren çalışanların, iş verimliliğinin daha yüksek olduğu görülmüştür. Kendi grubu dışındaki çalışanlarla daha sık etkileşime giren, ilişkisel beceriklilik ile davranan çalışanların verimlilik seviyeleri gelişim göstermiştir.

Bilişsel beceriklilik Boyutu: İş görevlerinin ve işyeri ilişkilerinin anlamının veya amacının algılanması ve yorumlanması ile ilgili bir çalışanın anlayışında yeniden çerçevelenmesini içerir (Miller, 2015: 34). Bilişsel beceriklilik, kişinin işi üzerinde etki yaratmasına olanak sağlayarak farklı bir iş yolu oluşturmasına izin verir. Ayrıca, bireylerin çalışmalarının daha geniş kapsamlı etkilerini algılamalarına ve işlerini, hayatlarının bir parçası yapan değeri, belirlemelerini sağlar (Slemp ve Vella-Brodrick, 2013: 128). 


\subsection{Petrou, Demerouti ve Schaufeli Tarafından Yapılan Boyutlandırma}

Petrou, Demerouti ve Schaufeli tarafından iş becerikliliği kavramı; Kaynak Arayışı (seeking resources), Zorlu Görev Arayışı (seeking challenges) ve İş Talepleri Azaltmak (reducing demands) olmak üzere aşağıda özetlenen şeklinde boyutlandırılmıştır. Bu kavramsallaştırılan davranış boyutlarının, çalışanların iş koşullarını iyileştirmek için belirli iş yönlerini yeniden şekillendirdiği ileri sürülmektedir (Petrou vd., 2015: 471- 473; Petrou vd., 2012: 1122).

Kaynak Arayışı Boyutu: Geri bildirim veya bilgi arama gibi iş yerinde yardım arayan davranışlardır. Çalışanlar ihtiyaç duyduğu bilgileri elde ederek, görevlerini gerektiği gibi yerine getirirler ve yeni durumlara uyum sağlamayı kolaylaştırırlar. Örneğin; örgüt yöneticilerinden ya da çalışma arkadaşlarından tavsiye istemek gibi davranış biçimleri, çalışanların tükenme riskini de azaltmaktadır. Böylece azalan belirsizlik duyguları, onlara güçlü bir sosyal destek ağı sağlar. Diğer taraftan kaynak arayışının çalışan performansını da yükselttiği (Tims vd., 2012) ifade edilmektedir.

Zorlu Görev Arayıșı Boyutu: İşte motive olmaya yönelik, iş taleplerinde değişiklikler yapmaktır. Örneğin; bir çalışanın işinde daha fazla sorumluluk istemesi gibi; bu tür zorlu görev arayışı ile çalışanın, yüksek iş başarısı elde etmek için beceri sağlamaya yöneldiği ve sonucunda tükenmişliğe karşı esnek bir strateji oluşturulduğu ifade edilmektedir. Araştırmalara göre, iş yerinde karşılaştığ1 zorluklar, kişinin başa çıkma kaynaklarını harekete geçirir ve "üstün performans " ile sonuçlandırır (Lazarus, 1993: 5).

İş Taleplerini Azaltmak Boyutu: Yüksek ya da engelleyen iş taleplerinin azaltılması anlamına gelmektedir (Bipp ve Demerouti, 2015: 632). Örneğin; duygusal, zihinsel veya fiziksel olarak zorlu iş yönlerini ortadan kaldırmak gibi. İş taleplerinin kapasitesini aştığını algılayan çalışanlarda, iş taleplerinin azaltılması, bireyin refahını koruyarak, iş ile başa çıkmasında bir işlev görebilmektedir (Tims vd., 2012).

\section{4. İŞ BECERIKLILIĞİiNE İLIŞKİN YAKLAŞIMLAR}

Literatür incelendiğinde iş becerikliliğine ilişkin yaklaşımların, İş tasarımı teorisi ve İş̧ talepleri ve kaynakları modeli çerçevesinde şekillendiği görülmektedir.

\section{1. İş Talepleri Ve Kaynakları Modeli}

İş becerikliliği kavramı, iş tasarımı teorisi yaklaşımından farklı olarak Tims ve Bakker (2010) tarafından, İş talepleri ve kaynakları modeli (Job Demands-Resources Model, JD-R) perspektifinden açıklanmaya çalışılmıştır. İş talepleri ve kaynakları modeline göre iş becerikliliği, "çalışanların iş talepleri ve iş kaynaklarını, kişisel tercih ve yetenekleri ile uyumlu hale getirmek için yapabileceği değişikliklerdir" (Tims ve Bakker, 2010: 3).

JD-R modelinin temel varsayımı; çalışanların bilişsel sağlıklarının korunması ve iş kaynaklı gerginliklerin engellenmesine yönelik kişi-iş uyumlu tatmin edici işlevsel çaba göstermeleridir (Yavuz ve Artan, 2019: 103). Model çerçevesinde çalışanların, işlerinin hangi yönlerini proaktif bir şekilde değiştirebileceği tanımlanarak; 'iş talepleri (job demands)' ve 'iş kaynakları (job resources)' olmak üzere iki genel kategoriden oluşan, her işi karakterize eden, iş özellikleri odaklı bir yaklaşım geliş̧irilmiş̧ir (Tims vd., 2016: 45).

İş talepleri ve kaynakları modelinde, her çalışma ortamı genel bir model içerisinde ele alınsa da, aslında her biri benzersiz özelliklere sahiptir. Bu yaklaşım doğrultusunda modelin, iş özellikleri modeli ve talep kontrol modeli gibi önceki iş tasarım modellerine göre daha esnek ve seçici olduğu öne sürülmektedir (Tims ve Bakker, 2010: 3).

İş talepleri ve kaynakları modeline göre, iş özellikleri meslekler arasında büyük ölçüde değişebilir, ancak her zaman iş talepleri ve iş kaynakları biçiminde iki kategoriye ayrılmaktadır. İş talepleri, enerji ve çaba gerektiren iş yönleridir. Örneğin; aşırı iş yükü ile karşılaşılması ya da iş arkadaşları ile yaşanan çatışma gibi. Buna karşılık, iş kaynakları çalışanların, iş talepleriyle başa çıkmasına ve iş hedeflerine ulaşmasına yardımcı olan yönlerdir. İş performansı hakkında geri bildirimleri buna örnek olarak vermek mümkündür (Wang vd., 2017: 186). Aşağıda Şekil 2'de İş talepleri ve kaynakları modeli gösterilmiş̧ir. 
Şekil 2: İş Talepleri ve Kaynakları Modeli

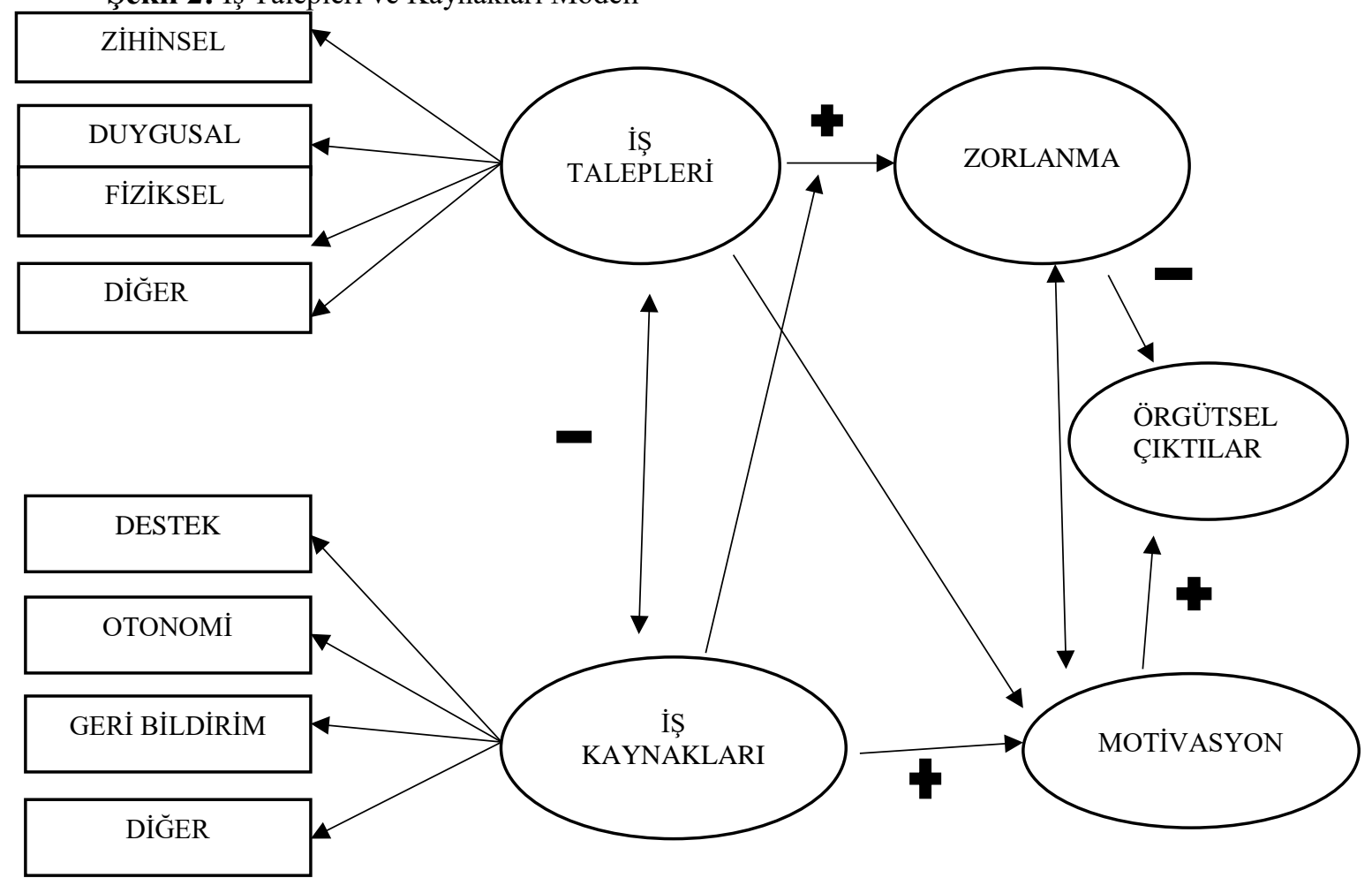

Kaynak: Bakker ve Demerouti, 2007: 313).

Şekil 2'de JD-R modelinde iş taleplerinin ve iş kaynaklarının temel faktörlerine ek olarak, işte zorlanma ve çalışan motivasyonun geliştirilmesinin iş talepleri ve iş kaynakları için önemli etkiye sahip olduğu ileri sürülmektedir. Aynı zamanda iş kaynaklarının, iş taleplerinin çalışanın işte zorlanma (iş yükü) üzerinde oluşturduğu etkiyi artırdığı görülmektedir (Bakker ve Demerouti, 2007: 314).

\subsection{1. İş Talepleri}

İş talepleri çalışanın, sürekli fiziksel ve/veya psikolojik (bilişsel ve duygusal) olarak çaba ve beceri gerektiren işinin fiziksel, psikolojik, sosyal veya örgütsel yönlerini ifade etmektedir. Bu nedenle iş talepleri, birey için belirli fizyolojik ve/veya psikolojik maliyetlerle ilişkilidir. Çalışma ortamının yüksek baskıya maruz kalınan bir alan olması, rahatsız edici fiziksel çalışma ortamı veya müşterilerle duygusal olarak kurulan zorlu etkileşimler iş taleplerine örnek oluşturabilir.

İş talepleri mutlaka negatif şekilde olmayabilir; ancak çalışanlar bu talepleri tam olarak karşılayamadıkları zaman, zihinsel olarak olumsuz yönde etkilenebilirler ve bu durum iş stresi yaşamalarını tetikleyebilir (Bakker ve Demerouti, 2007: 312).

Dış çevre kaynakları yetersiz olduğu durumlarda, bireyler yüksek iş taleplerinin potansiyel olarak olumsuz etkisini azaltamazlar ve bunun sonucunda iş hedeflerine ulaşamazlar. Benzer şekilde kendilerini işlerinde ya da örgütlerinde geliştirme firsatı yakalayamazlar (Bakker vd., 2004: 88). Diğer yandan alışanlar, örgütsel destek gibi yeterli kaynaklara erişebildiklerini hissettiklerinde (yüksek iş kaynakları), kendilerinden beklenen yüksek iş taleplerini daha az yıldırıcı olarak algılarlar ve işlerini sürdürmeye devam ederler (Cheng vd., 2016: 26).

\subsection{2. İş Kaynakları}

İş kaynakları, işin fiziksel, psikolojik, sosyal ve/veya örgütsel yönlerini ifade etmektedir. $\mathrm{Bu}$ yönleri aşağıdaki şekilde sıralamak mümkündür (Bakker ve Demerouti, 2007: 312);

- İş̧ hedeflerine ulaşmada işlevsel olan yönler,

- Fiziksel ve psikolojik maliyetlere yönelik olan iş taleplerini azaltan yönler,

- Kişisel gelişimi ve öğrenmeyi teşvik eden yönlerdir. 
İş kaynakları, çalışanın iş hedeflerine ulaşmasını sağlayan, iş taleplerini ve ilgili maliyetleri azaltan ve kişisel gelişimi teşvik eden işin belirli yönlerini ifade eder. İş talepleri- kaynakları modelinde, iş kaynakları, özellikle iş talepleri yüksek olduğu durumlarda çalışma motivasyonuna etki etmektedir (Bakker ve Demerouti, 2007).

İş talepleri-kaynakları modeline göre; iş talepleri yüksek olduğu ve iş kaynakları sınırlı olduğu durumlarda, mesleğin türüne bakılmaksızın çalışanlarda tükenmişlik geliştiği ileri sürülmektedir. Bunun nedeni, bu tür olumsuz çalışma koşullarının varlığının çalışanlarda ilk aşamada enerji düşürücü olması ve sonrasında da çalışma motivasyonlarını zayıflatmasıdır (Demerouti vd., 2001: 499).

Genel olarak, iş talepleri ve kaynakları olumsuz ilişkilidir, çünkü yüksek iş baskısı ve müşterilerle duygusal olarak zorlu etkileşimler gibi iş talepleri iş kaynaklarının harekete geçirilmesini engelleyebilir. Benzer bir şekilde, sosyal destek gibi yüksek iş kaynakları ve geri bildirimler de iş taleplerini azaltabilir (Bakker vd., 2004: 86).

\section{2. İş Tasarımı Teorisi}

İş tasarımının tarihi, büyük Mısır piramitlerini inşa eden eski Mısır medeniyetine kadar uzanmaktadır. İş tasarımı ilkeleri ilk olarak Smith (1776) ve Babbage (1835)'in eserlerinde ele alınmış, iş bölümünün verimliliği nasıl geliştireceğine dair açıklamalarda bulunulmuştur. Taylor (1911) tarafından geliştirilen bilimsel yönetim modelinde de, iş bölümü kavramı ve işi basitleştirmeye ilişkin tasarlanan teknikler yer almıştır. Daha sonra 1924-1933 yılları arasında Western Electric Company'nin Hawthorne Works'de yaptığı çalışmalar iş tasarımına önemli katkı sağlamıştır. Bir diğer büyük katkı da Herzberg ve arkadaşları tarafından1959 da Motivasyon-Hijyen Teorisi’nin (Çift Faktör Teorisi) geliştirilmesi ile sağlanmıştır. İş tasarımına yapılan en büyük yenilik ise Hackman ve Oldham tarafından (1975) ileri sürülen İş Özellikleri Teorisi’dir (Başpınar ve Çakıroğlu, 2020: 21).

İş tasarımı; çalışan verimliliğine yönelik, iş ve insan unsurunu en uygun biçimde birleştirmeyi amaçlayan yönetsel bir uygulama şeklinde tanımlanmaktadır (Baysan, 2004: 33). Bu tasarım; çalışanların faaliyetleri, sorumlulukları, işleri kapsamında yerine getirmeleri gereken görevler ile bu görev ve sorumlulukların nasıl yapılandırıldığı ve planlandığına ilişkin bilgileri içermektedir (Daniels vd., 2017: 1118).

İş tasarımı teorisi, hem çalışanlar hem de işverenlerin yararına olacak şekilde iş özelliklerini değiştirmeyi ifade etmektedir. İş tasarımı sonucunda çalışanlar açısından; yüksek iş memnuniyeti ve artan iş motivasyonu gibi faydalar, organizasyonlar açısından ise; gelişmiş çalışan performansı, daha düşük iş devamsızlığı ve düşük karlı işletmelere faydalar sunan çıtılar elde edilmektedir (Miller, 2015: 14).

Geleneksel olarak iş tasarımı, işi yüklenen çalışanlardan ziyade, işin kendisine odaklı yaklaşımdır ve yapılacak olan işin yapısına ilişkin karar vermeyi ifade etmektedir (Foss, 2009: 873). İş tasarımı teorisi, iş ile ilgili değişiklik yapılmasına ilişkin kararı, örgüt ya da yöneticilere vermektedir (Akçakanat vd., 2019: 398).

Geleneksel iş tasarımı perspektifinde, yöneticiler çalışanlar için işleri yukarıdan aşağıya doğru tasarlarlar. Daha açık bir ifadeyle çalışanlar, görevsel ve işlevsel açıdan pasif alıcılardır; ancak iş becerikliliği teorisinde, çalışanlar proaktif rolde kendi inisiyatifleri ile değişiklikler yapmaktadır (Miller, 2015: 33). Literatürde incelendiğinde başlıca iş tasarımı teknikleri arasında; iş basitleştirme, iş genişletme, iş zenginleştirme, iş rotasyonu, özerk çalışma grupları ve esnek çalışma kavramlarına yer verildiği görülmektedir (Yavuz, 2018: 14).

Wrzesniewski ve Dutton (2001), iş becerikliliğinin örgütsel psikoloji literatürüne hakim olan iş tasarımı perspektifinden farklı olduğunu ileri sürmektedir. İş tasarımı perspektifi, çalışanların yöneticiler tarafindan yeniden tasarlanan iş tanımlarına yanıt verdiğini varsayarken; iş becerikliliği, çalışanların işlerini yaparken işlerinin tasarımını bireysel olarak sürekli şekillendirdiğini ve etkilediğini öne sürmektedir (Tims vd., 2016: 45). İş becerikliliğinin iş tasarımı kavramından ayrıldığ diğer bir nokta; iş becerikliliği çalışanların iş unsurlarını, çalışma ortamındaki sosyal çevreyi ve işin anlamlılığını incelemeye yarayan çalışanlar arası ilişkileri ve değiştirdikleri iş süreçlerini ele almasıdır. Diğer yandan iş tasarımının, görev öğelerinin daha statik olduğu iş deneyimlerine odaklanması olduğu görülmektedir (Wrzesniewski ve Dutton, 2001: 181). 
İş tasarımında, örgütsel çaba ile işin değiştirilmesi, çalışan motivasyon ve memnuniyetinin sağlanması güdülenmektedir. Bazı iş tasarım yaklaşımları, bireyin kendi inisiyatifini öne çıkarsa da genel olarak iş tasarım uygulamaları çalışan ile değil, yönetim tarafindan düzenlenmektedir. İş becerikliliğinin ayrıştığı diğer bir yönü de çalışma ortamında sosyal etkileşimi vurgulayan rolüdür (Dvorak, 2014: 17).

$\mathrm{Bu}$ çerçevede iş tasarımının yukarıda aşağıya, iş becerikliliğinin ise aşağıdan yukarıya doğru uygulanan bir yaklaşım sergilediği söylemek mümkündür. Sonuç çıktıları ele alındığında ise, her iki yaklaşımında çalışanların iş tatminini arttırmaya amaçlayarak, onları motive ettiği görülmektedir (Başpınar ve Çakıroğlu, 2020: 22).

\section{5. İS BECERIKLILIIĞININ İLISSKKILİ OLDUĞU KAVRAMLAR}

İş becerikliliğine yönelik yapılan çalışmalarda, bulgular incelendiğinde örgütsel psikoloji tarihi içerisinde, bazı kavramlar ile benzerlik taşıdığı görülmektedir. Çalışmanın bu kısmında iş becerikliliği ile ilişkili olduğu düşünülen; örgütsel vatandaşlık davranışı, rol yenilikçiliği, görev revizyonu, bireysel inisiyatif alma ve yaratıcı performans kavramları üzerinde durulacaktır.

\section{1. Örgütsel Vatandaşlık Davranışı}

1980’li yıllarda örgütsel araştırma alanına giren ‘örgütsel vatandaşlık davranışı', herhangi bir direktife dayalı olmayan, örgüt yapılan davranışları nitelemektedir. Çalışanların formal rol davranışlarından farklılaşarak, informal görevlerde çalışanın gönüllü katılımını temsil etmektedir. $\mathrm{Bu}$ kapsama dayalı olarak literatürde, ekstra rol davranışı, prososyal davranış veya sesini duyurma davranışı ve bağlamsal performans şeklinde tanımlamalara rastlanmaktadır (Başpınar ve Çakıroğlu, 2020: 35).

Örgütsel vatandaşlık davranışı kavramı, ilk kez Organ (1988: 4) tarafindan kullanılarak; diğergamlık, vicdanlılık, nezaket, sivil erdem ve centilmenlik şeklinde beş boyutta sınıflandırılmıştır. Diğergamlık, çalışanın örgüt içinde diğer bireylere yardımda bulunmasını ve işe ilişkin sorunları önlemeye yönelik gönüllü şekilde davranmasını tanımlar. Vicdanlılık, çalışanın kendisinden beklenen görevlerin daha fazlasını gönüllü olarak sergilemesidir. Nezaket, çalışanın örgüt içinde diğerlerini ilgilendiren kararları almadan önce bilgilendirme davranışında bulunmasıdır. Sivil erdem, çalışanın örgütü etkileyen durumlarda kendini sorumlu addetmesi ve karar alımına, toplantılara sorumlu ve gönüllü olarak katılmasıdır. Centilmenlik ise, çalışanın işe ilişkin zorlukları şikayet etmeden kabul etme istekliliğidir.

Örgütsel vatandaşlık, örgüt içi bireyleri ya da örgütün kendisini desteklemeyi amaçlar. Bunun yanı sıra nezaket, vicdanlılık, diğerkamlık ve sivil erdemliliğin olduğu fedakarlık davranışlarını barındırmaktadır (Niessen vd., 2016: 1290).

Genel çerçevede örgütsel vatandaşlık, örgüte veya örgüt içerisinde başkalarına fayda sağlamayı hedeflerken; iş becerikliliği, işin anlamlılığı ve iş kimliğini değiştirmek için görevsel ve ilişkisel değişiklikler yapmaya odaklanmaktadır.

Bazı iş becerikliliğine ilişkin davranışlar, örgütsel vatandaşlık davranışlarına benzer nitelikte olabilir. Örneğin, çalışanın iş projelerini diğerleriyle birlikte üstlenmesi ya da müşteriler ile iyi ilişkiler kurmaya yönelik çalışanın ekstra çaba sarf etmesi gibi. Burada dikkat edilmesi gereken husus, davranışın arka planında diğer çalışanlara veya örgüt yararına bir niyetin olmamasıdır. Aksine iş becerikliliği çalışanın, bireysel çıkarına yönelik, işi daha anlamlı hale getirme arzusu ile güdülenmesidir (Wrzesniewski ve Dutton, 2001: 190).

İş becerikliliği davranışı sergileyen bireylerin, iş özelliklerine göre yaptıkları değişikliklerin, öncelikli olarak kişi-iş uyumunu (person-job fit) ve iş motivasyonunu geliştirmeyi amaçladığı göz önüne alındığında, kavramsal çerçevede, bireysel inisiyatif veya örgütsel vatandaşlık davranışı gibi ilgili yapılardan açıkça ayırt edilebilir olduğu görülmektedir (Bipp ve Demerouti, 2015: 632).

Örgütsel vatandaşlık davranışının, organizasyonel amaç ve hedeflere yönelik hizmet etmesi ile iş becerikliliği kavramından ayrıldığı söylemek mümkündür. İş becerikliliği, çalışanların kişisel yetenekleri ve yönelimleri doğrultusunda gerçekleşen bir davranış şeklidir (Kerse, 2017: 287). 


\subsection{Rol Yenilikçiliği}

Rol yenilikçiliği, bireylerin, liderlerin ve örgütlerin çıktıları arttırmayı amaçlayan rol değişiklikleri başlatması şeklinde tanımlanabilir (Başpınar ve Çakıroğlu, 2020: 28).

Rol değişiklikleri, görev hedefleri, yöntemleri, dokümanları, zamanlanması ve görev performansıyla bütünleşik biçimde bireylerarası ilişkilerde yapılan değişimleri kapsamaktadır. Rol yenilikçiliğinde birey ve örgüt uyumunun sağlanması için işe ilişkin değişiklikler yapılması, iş becerikliliği ile benzerlik göstermektedir. Her iki kavramda birey-örgüt uyumunu yükselten çıktılar elde edilmektedir. Bununla birlikte, rol yenilikçiliği kavramının odağında reaktif davranış ve özellikle gruplara yönelik sorunları çözme vardır. İş becerikliliğinde ise, örgütün problemlerine ilişkin bir odaklanma yerine, çalışan iş kimliğine ve işin anlamlılığının yükseltilmesi için iş sınırlarında yapılan proaktif değişikliğe vurgu yapılmaktadır (Wrzesniewski ve Dutton, 2001: 188; Yavuz, 2018: 18).

\subsection{Görev Revizyonu}

Staw ve Boettger (1990: 527) tarafından görev revizyonu, "örgütte hatalı bir prosedürün, yanlış bir iş tanımının veya işlevsiz olan rol beklentisinin düzeltilmesi için yapılan eylemler" şeklinde kavramsallaştırmıştır. Araştırmacılara göre, çalışanlar sorumluluklarını yerine getirirken alternatifler açı ve belirgin ise kendi inisiyatifleri ile daha fazla görev revizyonunda bulunabilmektedir.

Görev revizyonu, iş tasarımı alanında yeni bir kavram olarak görülmektedir. Görev revizyonu çalışanların kendi inisiyatifleri ile yanlış belirlenmiş bir rolü ya da işi değiştirirken yenilikçi bir yaklaşım benimsemesidir. $\mathrm{Bu}$ yaklaşıma göre, örgütsel roller ve iş tanımları, doğru ya da yanlış biçimde tanımlanmış olabilir. Rol eğer doğru tanımlanmış ise çalışan davranışı ile uyum gösterir ve yüksek performans beklenir; diğer taraftan, yanlış bir rol tanımlamasıyla karşılaşıldığında görev revizyonu, düzeltme eğilimi sergiler ve olası performans düşüklüğünü engelleyici rol üstlenir (Başpınar ve Çakıroğlu, 2020: 30).

Örgütsel roller yanlış biçimde tanımlandığında (çalışan perspektifinden) görev revizyonunun bu duruma değerli bir sonuç oluşturulacağı düşünülmektedir. Diğer taraftan sadece yanlış iş prosedürlerinin düzeltilmesi ya da zorlukları çözümlemeye odaklanan değişimler, görev revizyonunu iş becerikliliğinden ayırmaktadır. İş becerikliliği bakış açısında, görevlerin bütünüyle uyumlu ve işlevsel olduğunda da yararlı olduğu ve böyle bir iş çıktısının, işin anlamlılığını da geliştireceği ileri sürülmektedir (Wrzesniewski ve Dutton, 2001: 190).

\subsection{Bireysel İnisiyatif Alma}

"Bireysel inisiyatif; bireyin işte aktif ve kendisinin başlattığı bir yaklaşım benimsemesine ve belirli bir işte resmi olarak gerekli olanın ötesine geçmesine neden olan bir davranış sendromudur" (Frese vd., 1997: 140).

Bireysel inisiyatif alma, davranış yönleri ile karakterize edildiğinde; örgüt misyonu ile uyumlu, uzun vadeli bir odak noktasına sahip olan, hedefe yönelik ve eylem odaklı, engeller ve aksilikler karşısında ısrarcı ve kendi kendini başlatan, proaktif bir davranış biçimi şeklinde tanımlanmaktadır (Frese vd., 1996: 38).

Bireysel inisiyatif alma, hem çalışmayan bireylerin kendi inisiyatifleriyle iş bulmalarını ya da kendilerine bir iş alanı oluşturmalarını hem de şirket düzeyinde örgütsel etkinliği artırdığı düşüncesi ile pratik ve teorik açıdan önemli bir kavram olarak görülmektedir (Frese vd., 1997: 139).

Bireysel inisiyatif alma, formal iş gereksinimlerinin ötesine geçen, ancak örgütsel hedeflere hizmet eden çalışanların, kendi inisiyatifiyle başlayan davranış biçimi olarak tanımlanmaktadır. Bireysel inisiyatif sergileyen bireylerin odak noktasında uzun vadeli ve geleceğe yönelik faaliyetler bulunmaktadır. Bu tür çalışanların, engeller ortaya çıktığında çözümlemek için ısrarcı oldukları öne sürülmektedir. İş becerikliliği kavramı, örgütsel hedeflere daha az ölçüde hizmet etmesi ve problem çözmeye daha az odaklanması nedeniyle bireysel inisiyatif alma kavramından farklılaşmaktadır (Niessen vd., 2016: 1290). 


\subsection{Yaratıcı Performans}

Oldham ve Cummings (1996: 608) tarafindan yaratıcı performans; (1) yeni veya orijinal olma, (2) bir örgüt için potansiyel olarak uygun veya yararlı olma, şeklinde iki koşulu sağlayan ürünler, fikirler veya yöntemler olarak tanımlanmıştır.

Yaratıcı performans, ișlerin daha yüksek bir performans ile yapılmasını veya bir iș rolünü daha verimli hale getirmek için işe yeni fikirler ve/veya yöntemler getirilmesini ifade etmektedir. İş becerikliliğiyle benzer yönleri, çalışanın gönüllülük esası ve iş yönlerinin değiştirilmesidir. Kavramsal olarak örgüt içinde oynadıkları roller açısından iş becerikliliği ile benzese de; iş becerikliliği temel de birey odaklıyken, yaratıcı performans örgüt odaklı bir yaklaşımdır (Dvorak, 2014: 16-17).

Her iki yaklaşım da yeni fikir ve süreçlerin ortaya çıkmasına öncülük etmekte ve içsel güdülerin varlığını içermektedir; ancak yaratıcı performans spesifik olarak bireysellik ile bağlantılıdır ve temelinde örgüt hedeflerinin karşılanması yer almaktadır. Genel perspektifte bakıldığı zaman iş becerikliliğini diğer kavramlarda öne çıkaran yönler aşağıda sıralanmıştır (Yavuz, 2018: 20);

- Görevleri en iyi şekilde yerine getirmek ve işinde uzman olma,

- İşinde bir sanatçı gibi tasarımlar yaparak, işini bir sanat haline getirme,

- Kendi normlarını diğer bireylere kabul gördürme,

- İhtiyaç ve istekleri ile uyumlu bir çalışma ortamı kurmak için çaba sarf etme,

- İşini anlamlı görerek, bireysel amaçlı bir iş kimliği yaratmaktır.

\section{6. İŞ BECERÍKLILIIĞININ SONUÇLARI}

İş becerikliliği ile çalışanlar, iş taleplerini ve kaynaklarını proaktif bir şekilde değiştirebilirler ve bunun sonucunda bireysel çalışma ortamlarını iyileştirebilirler/ optimize edebilirler (Bakker ve Oerlemans, 2019: 417). İş becerikliliği sayesinde, çalışanlar bir yandan kişisel ihtiyaçlarını ve yeteneklerini geliştirirken diğer taraftan iş özellikleri ile aralarındaki uyumu yakalarlar (Wingerden vd., 2017: 165).

İş becerikliliği kavramı, çalışanın iş görevlerini ve etkileşimlerini ne zaman ve ne şekilde tasarlayacağına kendi inisiyatifi ile karar verdiği bireysel düzeyde bir faaliyettir. Çalışanların kendi yararına yaptığı davranışlar, örgüte yarar da sağlayabilir, zarar da getirebilir. Bu durum iş becerikliliği faaliyetinin birey yanlısı olduğunu göstermektedir; ancak örgüt düzeyinde 'iyi' ya da 'kötü' olup olmadığı, koşul ve şartlara göre değiş̧iklik gösterebilir. Örneğin, otomobil montaj hattında çalışan bir kişi, görevinde değişiklik yapmaya karar verdiğinde; ya yenilikçi yöntemiyle üretkenliği ve kaliteyi artırabilir ya da iş akışında öngörülmeyen sorunlara neden olabilir (Wrzesniewski ve Dutton, 2001: 187).

İş becerikliliğinin temelinde, çalışanların iş ile uyumlarını ve iş motivasyonlarını geliştirme yatmaktadır (Bipp ve Demerouti, 2015: 632). İșe anlamlılık katan bu davranışların sonucunda ise, örgütün yenilikçiliğine de katkıda bulunan, örgüte fayda sağlayan davranışlarda bulunabilmektedir. Diğer taraftan, çalışanın bireysel iş yükünü azaltıcı yeni alternatifler uygulaması, çalışma arkadaşının iş yükünü artırma gibi beklenmeyen olumsuz çıktılara da sebep olabilir (Yavuz, 2018: 107).

Tims, Bakker ve Derks (2013: 238) tarafindan yapılan araştırmada iş becerikliliği ve iyi oluş arasındaki ilişki, JD-R çerçevesinde incelenmiş, zorlu iş taleplerinin çalışan iyi oluşuna doğrudan ve pozitif yönlü bir etkisi olduğu görülmüştür. Çalışmada işleri üzerinde bireysel inisiyatif sahibi çalışanların, öznel iyi oluşlarında artış meydana geldiği sonucuna varılarak; örgüt içinde çalışana daha fazla aktif rol verilmesi gerektiği ileri sürülmüsstür.

İş becerikliliğine ilişkin yapılan bir diğer çalışmada, iş becerikliliğinin çalışan iş tatmini ile yakından ilişkili olduğu görülmüştür (Cheng vd., 2016: 19). İş yerinde yapılan gönüllü değişiklikler, iş tatmin düzeyini yükseltmektedir. Doğru orantılı bir şekilde, işinde tatmin duygusu yaşayan bireylerin de iş becerikliliği davranışı sergilediği görülmektedir (Başpınar ve Çakıroğlu, 2020: 79).

İş-aile zenginleşmesinde iş becerikliliği rolünü inceleyen Rastogi ve Chaudhary (2018: 652653), değişkenlerin arasında, güçlü bir ilişki olduğunu gözlemlenmiştir. Araştırmacılara göre, iş 
becerikliliği yaklaşımıyla, işleri üzerinde proaktif davranış gösteren bireylerin, kişisel ihtiyaç ve yetenekleri ile uyumlu iş talepleri ve kaynaklarına yönelik tasarımları, kişi-iş uyumu yaratarak iş-aile zenginleşmesine neden olmaktadır. Benzer doğrultuda işe yönelik yapılan görevsel, ilişkisel ve bilişsel değişiklikler, iş ve aile sorumluluklarının yerine getirmesinde çalışanı daha donanımlı kılmaktadır. Birey iş ortamında kazandığı olumlu duyguları ve eylemleri işten aileye aktararak, ev alanındaki yaşam kalitesini de yükseltmektedir. Sonuç olarak çalışanın bu zenginleştirme yeteneği, iş-aile zenginleşme düzeyini belirlemede etkili rol oynamaktadır.

Dalgıç ve Türkoğlu (2018: 787) tarafından, otel çalışanları ile gerçekleştirilen araştırmada, işlerini kişisel özellikleri doğrultusunda yeniden dizayn eden çalışanların polikronik kişilik özelliği ile iş becerikliliği davranışlarının yüksek seviyede olduğu gözlemlenmiştir. Çalışmanın sonucunda iş becerikliliği ve polikronik kişilik özelliğinin, otel çalışanlarında işten ayrılma niyetini azalttığı bulgulanmıştır.

İş becerikliliğine yönelik yapılan bir diğer çalışma Kerse (2017: 298) tarafindan bir sanayi işletmesinde gerçekleştirilmiştir. Araştırma sonucunda, çalışanların iş becerikliliği yükseldikçe, duygusal tükenmenin azaldığı görülmüştür. Kerse, günümüzde örgütler için büyük sorun teşkil eden duygusal tükenmenin, iş becerikliliği eksikliğinden kaynaklandığını ileri sürmüştür.

Akçakanat ve arkadaşlarının (2019: 409) 230 İK yöneticisi ile gerçekleştirdikleri araştırmada, Tims ve ark. (2012) tarafından geliştirilen sınıflandırma kullanılmıştır. Proaktif rol üstlenen çalışanların, işe olumlu yaklaşımının, iş kaynaklarını artırarak, işe adanmışlık duygusunu tetiklemektedir. Çalışma sonucunda, iş becerikliliğinin, yapısal iş kaynaklarını artırma, sosyal iş kaynaklarını artırma ve zorlayıcı iş gerekliliklerini artırma boyutlarının, işe adanmışlık duygusuna pozitif ve anlamlı etkisinin olduğu ortaya konmuştur. Genel olarak, çalışanların bireysel ihtiyaçları ve yeteneklerinin, çalışma ortamının fırsat ve talepleri ile eşleşmesinde iş becerikliliği yaklaşımının ön gördüğü, proaktif kişi ve çevre uyumu davranışlarının anahtar rol aldığını söylemek mümkün olmaktadır (Tims vd., 2016: 44).

\section{SONUÇ}

Global dünya düzenindeki teknolojinin hızlı akım versiyonları, örgüt ve temel taşı niteliğinde olan çalışanları, karmaşık bir yapıya sürüklemektedir. Bu karmaşıklığın öngörülebilir düzlemde çözümlenebilmesi noktasında literatüre yeni kazandırılan iş becerikliliği kilit kavram olarak karşımıza çıkmaktadır. Araştırmalar, artan belirsizlikler sonucunda, çalışanın karşılaştığı iş gücü çeşitliliği ve buna bağlı gelişen kişiye uygun olmayan, zorlu görev ve sorumluluk tayinleri ile başa çıkmak için iş becerikliliği yaklaşımını çözüm yolu olarak ileri sürmektedirler. Bu doğrultuda çalışanı öğrenmeye ve ek beceriler kazanmaya teşvik eden, aynı zamanda yeteneklerini geliştirmesi için daha fazla iş kaynağı fırsatları sunan iş becerikliliği öne çıkmaktadır (Zhang ve Parker, 2019: 126; Rastogi ve Chaudhary, 2018: 669).

21. yüzyılın başlarında, örgütsel psikoloji alanındaki araştırmacılar, sadece iş stresi ve tükenmişlik gibi negatif iş konularına odaklanmak yerine işin pozitif tarafiyla gittikçe daha fazla ilgilenmeye başlamıştır. Pozitif psikoloji hareketi, tüm dünyadaki araştırmacılara yeni modeller ve kuramlar geliştirmeleri için ilham vermiştir. Diğer taraftan uzun zamandır tanımlanmasına rağmen iş becerikliliği ile ilgili araştırmalar yalnızca son on yılda artış göstermiştir (Başpınar ve Çakıroğlu, 2020: 7). İş becerikliliği, pozitif örgütsel psikolojiye iki önemli katkı sunmaktadır. İlk olarak; iş becerikliliği süreci, çalışanların proaktif davranışlarını merkeze koyarak, iş deneyimlerini geliştirmek için işlerini değiştiren çalışanların, yaratıcı ve motivasyonel alt yapılarını kavramsallaştırarak ampirik biçimde araştırılma alanı oluşturmaktadır. İkincisi, pozitif anlam ve benlik duygusu, örgütsel bağlılık, adanmışlık ve performans deneyimi de dahil olmak üzere, iş becerikliliği davranışının üretken sonuçlarına odaklanılması pozitif örgütsel psikoloji anlayışına katkıda bulunmaktadır (Wrzesniewski vd., 2013: 282).

İş becerikliliği, çalışanların iş özelliklerini algıladığı perspektiften şekillendirerek, yapısal ve sosyal iş kaynaklarını artırmaya yönelik davranışlar sergilediği, aynı zamanda zorlu iş taleplerini artıran ve engelleyen iş taleplerini azaltan hedeflere yönelik proaktif bir iş davranışı şekli oluşturmaktadır (Rudolph, 2017: 113). Örgüt içerisinde, aşağıdan-yukarıya (Demerouti, 2014: 242) işleyişle, işlerinde proaktif davranış sergileyen (Tims ve Bakker, 2010: 1) çalışanların, temelde birey esaslı (Dvorak, 2014: 
17) iş becerikliliği yaklaşımıyla işlerini daha fazla anlamlı hale getirdiği ve iş kimliği kazandığı çalışmalarla elde edilmiştir (Wrzesniewski ve Dutton, 2001).

Çalışmada ele alınan araştırmalarda görülmüştür ki, iş becerikliliği sayesinde çalışanlar, kendilerine alternatif iş adımları oluşturarak; iş tatmini, iyi-oluş, örgütsel vatandaşlık, iş-aile zenginleşmesi, işe adanmışlık ve iş kimliği gibi birey-örgüt uyumlu organizasyon yapı oluşumuna önemli katkılar sağlamaktadır (Ingusci vd., 2016; Bakker ve Demerouti, 2007; Irvin, 2017; Rastogi ve Chaudhary, 2018; Crawford vd., 2010; Wrzesniewski ve Dutton, 2001).

Yapılan araştırma çerçevesinde, iş becerikliliği kavramının 'kişi-iş uyumu'nu destekleyen özelliği, İş sağlığı ve güvenliği uygulamalarının da temel amacı olan, 'işin insana, insanın işe uydurulması' koşulunun (Özkiliç, 2005) anlamlı derecede örtüştüğü düşünülerek, bu değişkenlerle yapılacak çalışmaların iş becerikliliği literatüründe gelecek çalışmalara ışık tutacağı düşünülmektedir.

\section{KAYNAKÇA}

Akçakanat, T., Uzunbacak, H. H., \& Acar, O. K. (2019). İnsan kaynakları yöneticilerinin iş becerikliliklerinin işe adanmışlıkları üzerine etkisi. OPUS Uluslararası Toplum Araştırmaları Dergisi, 10(17), 395-419.

Alfes, K., Shantz, A., \& Saksida, T. (2015). Committed to whom? Unraveling how relational job design influences volunteers' turnover intentions and time spent volunteering. VOLUNTAS: international journal of voluntary and nonprofit organizations, 26(6), 2479-2499.

Bakker, A. B., Demerouti, E., \& Verbeke, W. (2004). Using the job demands-resources model to predict burnout and performance. Human Resource Management: Published in Cooperation with the School of Business Administration, The University of Michigan and in alliance with the Society of Human Resources Management, 43(1), 83-104.

Bakker, A. B., \& Demerouti, E. (2007). The job demands-resources model: State of the art. Journal of managerial psychology.

Bakker, A. B., \& Oerlemans, W. G. (2019). Daily job crafting and momentary work engagement: A self-determination and self-regulation perspective. Journal of Vocational Behavior, 112, 417430.

Başpınar, N. Ö., \& Çakıroğlu, D. (2020). İş Becerikliliği (Job Crafting): Kuram ve Uygulama. Ankara: Detay Yayıncilik.

Baysan M., "Bir örgüt geliştirme tekniği olarak örgütsel alt sistemlere yönelik iş tasarımı teknikleri, Kara Havacılık Komutanlığı'nda bir uygulama”, Gazi Üniversitesi Sosyal Bilimler Enstitüsü, (Yüksek Lisans Tezi), Ankara 2004.

Berg, J. M., Wrzesniewski, A., \& Dutton, J. E. (2010). Perceiving and responding to challenges in job crafting at different ranks: When proactivity requires adaptivity. Journal of Organizational Behavior, 31(2-3), 158-186.

Berg, J. M., Dutton, J. E., \& Wrzesniewski, A. (2013). Job crafting and meaningful work.

Bipp, T., \& Demerouti, E. (2015). Which employees craft their jobs and how? Basic dimensions of personality and employees' job crafting behaviour. Journal of Occupational and Organizational Psychology, 88(4), 631-655.

Cheng, J. C., Chen, C. Y., Teng, H. Y., \& Yen, C. H. (2016). Tour leaders' job crafting and job outcomes: The moderating role of perceived organizational support. Tourism Management Perspectives, 20, 19-29.

Crant, J. M. (2000). Proactive behavior in organizations. Journal of management, 26(3), 435-462.

Crawford, E. R., LePine, J. A., \& Rich, B. L. (2010). Linking job demands and resources to employee engagement and burnout: a theoretical extension and meta-analytic test. Journal of applied psychology, 95(5), 834. 
Dalgıç, A., \& Türkoğlu, N. (2018). Otel Çalışanlarının İş Becerikliliği ve Polikronisite Eğilimlerinin İşten Ayrılma Niyetleri Üzerine Etkisi. ISAS, 3, 787-794.

Daniels, K., Gedikli, C., Watson, D., Semkina, A., \& Vaughn, O. (2017). Job design, employment practices and well-being: A systematic review of intervention studies. Ergonomics, 60(9), 11771196.

Demerouti, E. (2014). Design your own job through job crafting. European Psychologist.

Dvorak, K. J. "Theoretical development and empirical testing of the measure of job crafting (MJC)", Colorado State University, (Doktora Tezi), Colorado 2014.

Foss, N. J., Minbaeva, D. B., Pedersen, T., \& Reinholt, M. (2009). Encouraging knowledge sharing among employees: How job design matters. Human resource management, 48(6), 871-893.

Frese, M., Kring, W., Soose, A., \& Zempel, J. (1996). Personal initiative at work: Differences between East and West Germany. Academy of Management journal, 39(1), 37-63.

Frese, M., Fay, D., Hilburger, T., Leng, K., \& Tag, A. (1997). The concept of personal initiative: Operationalization, reliability and validity in two German samples. Journal of occupational and organizational psychology, 70(2), 139-161.

Ghitulescu, B. E. "Shaping tasks and relationships at work: Examining the antecedents and consequences of employee job crafting”, University of Pittsburgh, (Doktora Tezi), 2007.

Grant, A. M., \& Ashford, S. J. (2008). The dynamics of proactivity at work. Research in organizational behavior, 28, 3-34.

Ingusci, E., Callea, A., Chirumbolo, A., \& Urbini, F. (2016). Job crafting and job satisfaction in a sample of Italian teachers: the mediating role of Perceived Organizational Support. Electronic Journal of Applied Statistical Analysis, 9(4), 675-687.

Irvin, R. (2017). Job crafting and organizational citizenship behavior: Believing in your creative ability to better your job and organization (Doctoral dissertation, Kansas State University).

Kerse, G. (2017). İş becerikliliği (job crafting) ölçeğini Türkçe' ye uyarlama ve duygusal tükenme ile ilişkisini belirleme. İşletme Araştırmaları Dergisi, 9(4), 283-304.

Kerse, G. (2019). İş Becerikliliği ve İş Tatmini Arasındaki İlişsi: “İşe ilişkin değişiklikler, memnuniyeti artırabilir mi?”. Insan ve Insan, 6(20), 205-218.

Lazarus, R. S. (1993). From psychological stress to the emotions: A history of changing outlooks. Annual review of psychology, 44(1), 1-22.

Miller, M. L. "Relationships Between Job Design, Job Crafting, Idiosyncratic Deals, and Psychological Empowerment”, Walden University, College of Management and Technology, (Doktora Tezi), Minneapolis 2015.

Niessen, C., Weseler, D., \& Kostova, P. (2016). When and why do individuals craft their jobs? The role of individual motivation and work characteristics for job crafting. Human Relations, 69(6), 1287-1313.

Oldham, G. R., \& Cummings, A. (1996). Employee creativity: Personal and contextual factors at work. Academy of management journal, 39(3), 607-634.

Organ, D. W. (1988). Organizational citizenship behavior: The good soldier syndrome. Lexington Books/DC Heath and Com.

Özkiliç, Ö. (2005). İş Sağliği ve Güvenliği, Yönetim Sistemleri ve Risk Değerlendirme Metodolojileri. TiSK Yayınları, Ankara.

Parker, S. K., Bindl, U. K., \& Strauss, K. (2010). Making things happen: A model of proactive motivation. Journal of management, 36(4), 827-856. 
Petrou, P., Demerouti, E., Peeters, M. C., Schaufeli, W. B., \& Hetland, J. (2012). Crafting a job on a daily basis: Contextual correlates and the link to work engagement. Journal of Organizational Behavior, 33(8), 1120-1141.

Ghitulescu, B. E. "Shaping tasks and relationships at work: Examining the antecedents and consequences of employee job crafting”, University of Pittsburgh, (Doktora Tezi), 2007.

Rastogi, M., \& Chaudhary, R. (2018). Job crafting and work-family enrichment: the role of positive intrinsic work engagement. Personnel Review.

Rudolph, C. W., Katz, I. M., Lavigne, K. N., \& Zacher, H. (2017). Job crafting: A meta-analysis of relationships with individual differences, job characteristics, and work outcomes. Journal of Vocational Behavior, 102, 112-138.

Shin, Y., \& Hur, W. M. (2019). Linking flight attendants' job crafting and OCB from a JD-R perspective: A daily analysis of the mediation of job resources and demands. Journal of Air Transport Management, 79.

Slemp, G. R., \& Vella-Brodrick, D. A. (2013). The Job Crafting Questionnaire: A new scale to measure the extent to which employees engage in job crafting. International Journal of Wellbeing, 3(2).

Staw, B. M., \& Boettger, R. D. (1990). Task revision: A neglected form of work performance. Academy of Management Journal, 33(3), 534-559.

Tims, M., \& Bakker, A. B. (2010). Job crafting: Towards a new model of individual job redesign. SA Journal of Industrial Psychology, 36(2), 1-9.

Tims, M., Bakker, A. B., \& Derks, D. (2012). Development and validation of the job crafting scale. Journal of vocational behavior, 80(1), 173-186.

Tims, M., Bakker, A. B., \& Derks, D. (2013). The impact of job crafting on job demands, job resources, and well-being. Journal of occupational health psychology, 18(2), 230.

Tims, M., Derks, D., \& Bakker, A. B. (2016). Job crafting and its relationships with person-job fit and meaningfulness: A three-wave study. Journal of Vocational Behavior, 92, 44-53.

Wang, H. J., Demerouti, E., \& Le Blanc, P. (2017). Transformational leadership, adaptability, and job crafting: The moderating role of organizational identification. Journal of Vocational Behavior, 100, 185-195.

Wingerden, J. V., Bakker, A. B., \& Derks, D. (2017). Fostering employee well-being via a job crafting intervention. Journal of Vocational Behavior, 100, 164-174.

Wrzesniewski, A., \& Dutton, J. E. (2001). Crafting a job: Revisioning employees as active crafters of their work. Academy of management review, 26(2), 179-201.

Wrzesniewski, A., LoBuglio, N., Dutton, J. E., \& Berg, J. M. (2013). Job crafting and cultivating positive meaning and identity in work. In Advances in positive organizational psychology. Emerald Group Publishing Limited.

Yavuz, M. "İ̧ş zanaatkârlığı ile bireysel performans çıktıları arasındaki ilişkide çalışanların dışsal prestij ve kurum destek algılarının rolü”, Marmara Üniversitesi Sosyal Bilimler Enstitüsü, (Doktora Tezi), İstanbul 2018.

Yavuz, M., \& Artan, İ. E. (2019). İş Zanaatkarlığı (Job Crafting) Kavramı: Türkçe İş Zanaatkarlığ1 Ölçeği 'nin Geliştirilmesi. Dokuz Eylül Üniversitesi İşletme Fakültesi Dergisi, 20(1), 95-125.

Zhang, F., \& Parker, S. K. (2019). Reorienting job crafting research: A hierarchical structure of job crafting concepts and integrative review. Journal of Organizational Behavior, 40(2), 126-146. 